\title{
Assessment of Project Manager's Competence in the Context of Individual Competence Baseline
}

\author{
Mariusz Sołtysik $^{1, *}$, Małgorzata Zakrzewska ${ }^{1}\left(\mathbb{D}\right.$, Adam Sagan $^{2}$ and Szymon Jarosz $^{1}$ \\ 1 Department of Management Process, Cracow University of Economics, Rakowicka 27, 31-510 Cracow, \\ Poland; malgorzatakazak.uek@gmail.com (M.Z.); szymonjarosz@poczta.fm (S.J.) \\ 2 Department of Market Analysis and Marketing Research, Cracow University of Economics, Rakowicka 27, \\ 31-510 Cracow, Poland; sagana@uek.krakow.pl \\ * Correspondence: soltysik@uek.krakow.pl
}

Received: 23 April 2020; Accepted: 15 May 2020; Published: 21 May 2020

\begin{abstract}
This study's aim is to determine the consistency of student opinions regarding the importance of individual skills in three areas-people, practice, and perspective-with expert assessment. The study group consisted of five-year students accredited by IPMA Poland. The team of experts was comprised of recruiters, project management lecturers, assessors, and information technology (IT) industry project managers. Our research shows divergences in the approach to key competence that a project manager should have. This is understandable, given the specifics of the comparison. However, the analysis that has been conducted and presented will allow the curricula to be revised. The subsequent evaluation of curricula should address the changes in the labor market. Education should provide key competences, especially as modern project management requires a full spectrum of competences and approaches. Besides experience, project management is the most frequently pursued competence that is required in terms of staff recruitment criteria. The research resulting figures may be useful for recruiters, certification institutions, and universities.
\end{abstract}

Keywords: competence; education; project management

\section{Introduction}

The growing popularity of project management and the demand for experienced project managers has made a specific contribution to academia. Therefore, recently project management has become an attractive field of study for students and, moreover, is predicted to gain importance and popularity in the future. This prediction stems from the fact that there is and will be a crucial need for agile organizations that are able to react quickly to the opportunities and risks that may encounter in a volatile economic environment. Education should live up to this need and equip graduates with appropriate competences that will allow future project managers to deal with project management challenges. Education program certification schemes account for enriching the education process. A successfully obtained certificate does not only increase the value of a candidate but also increases the level of trust among would-be colleagues, stakeholders, and partners. This article attempts to identify the key competence of a project manager in accordance with the requirements defined by the IPMA ICB 4.0. The IPMA ICB 4.0 [1] is a global standard that defines the competences required of people working in the field of projects, programs, and project portfolio management. The IPMA ICB 4.0 is based on previous editions and presents new insights and tips for a wider range of applications. It serves a wide audience, including employees of the education sector, trainers, project management practitioners, human resources specialists, and certification assessors. The IPMA ICB 4.0 is also a reference point for the assessment of individual competences in the IPMA four-level certification system. Moreover, the IPMA ICB 4.0 is an important next milestone on the road to effective and modern projects, programs, 
and project portfolio management. This version describes the three domains of specialized knowledge required in today's business. The IPMA ICB describes people who work in project management, avoiding role-specific terminology due to the universality of the standard application. The immediate objective has been to review the consistency of the student and project manager competence assessment with the requirements defined by the IPMA ICB 4.0. Our research may lead to an update in curricula with regard to present and future project management needs.

\section{Literature Review}

The approach to defining the concept of competences is diversified in the related literature. That diversification of the approach has contributed to the development of ever-new definitions of competences that are fundamentally different from one another. However, to this end, a deeper analysis captures elements common to the majority of definitions. Such elements may include knowledge, skills, and attitudes [2-4]. Those key factors are necessary for performing an effective or above-average job [5]. This is particularly important for a position of a project manager.

The growing popularity of project management is associated with the rising requirements for project managers [6], which means that there is growing pressure on people holding this position [7]. This is due to the fact that the skills of coping with stress and pressure are gaining importance in the work of a project manager. Contemporary organizations are characterized by design thinking. The project manager is the person who manages the entire project. The main responsibilities of the project manager throughout the entire project cycle are information management, activities, and teams. Therefore, this responsibility requires a high level of skills and competences that the project manager must use. The scope of competence of the project manager covers all individual characteristic areas, e.g., team manager, application manager, or service manager. The strong relationship between competences and project results proves project managers' competences level [8]. Requirements that a project manager should meet have their own characteristics and thus, for a project manager, emphasis is placed on skills and competences that are different from those of other managers [9]. These considerations lead us to the conclusion that a project manager should demonstrate competences that will help him or her combine various aspects of the project and flexibility in using the knowledge acquired during education and experience gained throughout the professional career of the project manager [10], including soft skills and emotional intelligence [11]. Therefore, it is crucial to coordinate the curriculum with the requirements of the professional work to be completed by project managers [12].

Project management has become a well-developed area of management and a source of professional knowledge in the field of scientific research and didactics [13], which is associated with adapting the education process to market requirements. Organizations take advantage of project and program management skills to achieve strategic benefits with growing frequency [14]. The most important determinants of a project's success are closely related to the manager's duties and competences [15]. Therefore, an employer's aim is to recruit employees who have a full spectrum of competences, approaches, and readiness to effectively implement the tasks assigned to them. The topic of entrepreneurial competences and education has gained scientific attention since 2008 and a variety of contributions have been published [16]. The importance of entrepreneurial and managerial competences is enhanced by the fact that they are closely linked to an organization's strategy and behavior that enables quick adaptation to an environment $[17,18]$. It must be empathized that such adaptation is crucial for a project manager, especially in the present volatile conditions.

Along with the growing popularity of the project manager profession and its growing importance, equally important is the work and research that has appropriately tailored human resource development practices [15]. There have been many studies on the competences of project managers that focus on competences in the field of [19-21], ignoring other key managerial competences. On the other hand, the number of competences that project managers need are increasing [6,22]. Effectiveness demands put pressure on managers too [7]. Therefore, project managers should have skills and competences different from other managers [9]. Project management primarily combines many project-related 
aspects that affect the achievement of the set goal. It should also be emphasized that the work of a project manager is not only a combination of "hard" knowledge and experience that is acquired throughout the professional career of a project manager [10], but also requires soft skills and emotional intelligence [23,24]. These are necessary for proper communication, conflict management [11], and relationship management by a person holding the position of project manager [25]. The same is applicable to knowledge management [26,27].

Due to the project manager's responsibilities, which include planning tasks and project effects [28] by means of an action development plan, schedule, and budget; delegation of powers and duties; stakeholder relations [29]; contact with contractors and final users [30]; contact with customers/clients; project implementation monitoring [31]; addressing project problems and the follow-up; crisis management [12,25], change management [26], or project management [32,33]; and recruitment of team members [23].

Thus, it is very important to successfully conduct the recruitment process for the position of project manager. Staff recruitment and selection is a complex process that aims to recruit a prospective person for a specific position who will best fit into an organization's philosophy [34]. Since recruiting the right person for a vacant position is crucial for the efficiency and success of organizational operations $[35,36]$, the people responsible for the recruitment process set out a wide variety of conditions and requirements that mitigate the risk of recruitment errors. Education is one of the factors that facilitates risk mitigation. Besides experience, project management is the most frequently pursued competence that is required in terms of staff recruitment criteria [12,37]. Education should be adapted to the new challenges determined by the globalization process [38,39].

The growing popularity of project management and the demand for experienced project managers have made a specific contribution to academia. Therefore, project management has become a very attractive field of study for post-graduate students and bachelor's degree or master's degree students in recent years. The development of new specialties is a response to numerous jobs on offer for the position of project manager. The project manager profession is considered by many to be the profession of the future, due to the fact that businesses must be agile and quick to adapt in our rapidly evolving and highly competitive environment, and project management is an appropriate answer to these conditions [40]. These trends are predicted to develop the role of project managers from deputy managers to responsible entrepreneurs [41], which is part of the previous consideration concerning the importance of entrepreneurial and managerial competence in project management. However, despite many candidates, recruitment for the position of project manager should be one of the most difficult. It is therefore important that education is adapted to market requirements. Education program certification schemes account for enriching the education process. A successfully obtained certificate not only increases the value of a candidate but also increases the level of trust among would-be colleagues, stakeholders and partners [42].

The article attempts to identify the key competences of a project manager in accordance with the requirements defined by the IPMA ICB 4.0. The immediate objective has been to review the consistency of the student and project manager competence assessment with the requirements defined by the IPMA ICB 4.0.

\section{Materials and Methods}

\subsection{Pilot Studies}

Before proceeding with the project manager competence assessment study, a pilot study was carried out to verify the correctness of the questionnaire and match its content to a group of intentionally selected respondents. The developed questionnaire was used for finding out student opinions on the competences of a project manager. Students, especially in those in the last years of study and postgraduate studies, despite their lack of practical experience in project management have great knowledge about the characteristics of the profession of project managers and their requirements. 
The sources of this knowledge are numerous workshops organized at universities by large corporations and recruitment agencies. In addition, the curricula implemented at universities give students the opportunity to practice managerial competences as part of the workshop. The questionnaire included 4 categories of requirements: education, qualification, experience, and individual competence. The entire questionnaire consisted of 46 closed-ended questions. Based on the results obtained within the framework of the pilot study, the questionnaire was evaluated in the following categories:

- consistency of the survey with the group of respondents;

- content and form of the survey question formulas;

- content and form of the responses given by respondents;

- structure of the questionnaire and sequence of questions;

- $\quad$ the survey procedure.

The results of the pilot study allowed us to assess the validity of the input figures of the statistical analysis of the results and the manner of presenting the outcome of the student opinion survey.

The main purpose of that stage of the research process was to verify the correctness and effectiveness of the research tool and its assessment on the basis of comments received from respondents during the interview about the structure and content of the questionnaire.

The pilot study was conducted among a group of 15 students enrolled for the Project Management Program at the Cracow University of Economics. The results of this study contributed to the enhancement of the questionnaire, which was altered to the necessary extent.

The outcome of the pilot study as well as the previously set criteria of evaluation of the research tool allowed us to formulate the following conclusions:

1. The content of the examined subject matter, i.e., the requirements that project managers need to satisfy during recruitment processes, coincided with the target group of the surveyed students. Unfortunately, based on the pilot study, it turned out that some of the questions regarding experience resulting from participation in recruitment processes for the position of a project manager did not apply to the research target group of respondents.

2. The content of the questions placed in the questionnaire was understandable and accessible to the group of surveyed students. The closed-ended part of the questionnaire was conducive to quick and correct answering of questions and also facilitated the efficient coding of data and subjecting it to the statistical analysis.

3. The categories of the answers contained in the closed-ended questions of the questionnaire provided by the participants of the pilot study were sufficiently suited to the position of students in terms of the requirements of recruitment processes for the position of project manager, however it was decided to leave the possibility of providing another answer by the respondents.

4. The structure of the questionnaire was assessed to have ensured a readable document. The length of the questionnaire was not assessed to be acceptable due to the doubled number of questions resulting from the occurrence of two parts of the questionnaire-for persons already participating in the recruitment process for the position of a project manager and for persons who had not yet experienced it. As a result of the pilot study, it was decided to leave in the questionnaire its part relating only to opinions on requirements, without taking into account the experience based on participation in the recruitment process.

5. Due to the length of the survey questionnaire and the closed-ended questions in the survey, the participants of the pilot study emphasized that the questionnaire would have been simpler to complete using an online questionnaire and it would have taken less time to complete it.

Based on the above conclusions, the questionnaire was modified. First of all, the content of the questionnaire was limited only to the part of the questions about the student opinion on the requirements that project managers need to satisfy in recruitment processes. 


\subsection{Characteristics of the Research Tool}

Data collection on the student opinion survey was performed using an online survey. Those questions took the form of closed-ended questions. Open-ended questions in that questionnaire were only a supplement to the answer given in the previous closed-ended question or the answer in the "Other" category. The survey included the overall number of 23 questions. The sequence of questions was related to the division of variables into categories: experience, individual competence, education, and professional qualifications. The survey consisted of three parts: formal and record-keeping, substantive, and final (record). The answer sheet contained 179 skills under 28 individual competences.

\subsection{Characteristics of the Research Sample}

The study group consisted of 5-year students enrolled on the Project Management or Management Program with a major in Project Management, namely the studies accredited by the International Project Management Association Poland, which is the international institution involved in the training and project manager certification scheme from the Cracow University of Economics, the Silesian University of Technology in Katowice, and the University of Szczecin. That choice made for the purpose of the study arose from the attempt undertaken by the students to assess the significance of the project manager competence defined by the IPMA Individual Competence Baseline version 4.0 (International Project Management Association; Switzerland; 2015), which is a set of project manager competence guidelines for the project, program, and project portfolio management. It is an extended set of competences, as compared to the previous versions, and divided into three areas: people, practice, and perspective. People who were supposed to have at least basic knowledge in the field of project management and knew the competence requirements of the Individual Competence Baseline were selected. In addition, those people were assumed to have chosen the project management program because they associated their professional career with that field of study. The questionnaire was sent to 186 people (representing $100 \%$ of all students at the above-mentioned universities). Those returned accounted for $35 \%$ of all the questionnaires that had been sent. The research sample included 65 people. Table 1 presents descriptive characteristics for the selected variables.

Table 1. Descriptive characteristics for selected variables.

\begin{tabular}{cccc}
\hline Descriptive Statistics & Years of Experience & $\begin{array}{c}\text { Number of Known } \\
\text { Foreign Languages }\end{array}$ & $\begin{array}{c}\text { Number of } \\
\text { Recommendations }\end{array}$ \\
\hline $\begin{array}{c}\text { Number of } \\
\text { observations }\end{array}$ & 65 & 65 & 65 \\
\hline Minimum value & 1 & 1 & 1 \\
\hline Maximum value & 5 & 3 & 5 \\
\hline Interval & 4 & 2 & 4 \\
\hline Arithmetic average & 2.108 & 1.861 & 2.046 \\
\hline Modal value & 2 & 2 & 2 \\
\hline First Quartile & 1 & 1 & 2 \\
\hline Median & 2 & 2 & 0 \\
\hline Third Quartile & 2 & 2 & 0.732 \\
\hline Quartile interval & 1 & 1 & 0.856 \\
\hline Variance & 1.098 & 0.496 & 41.820 \\
\hline Standard deviation & 1048 & 0.704 & \\
\hline Coefficient of variation & 49.706 & 37.838 & 2 \\
\hline
\end{tabular}




\section{Statistical Analysis Resulting Figures}

\subsection{The Survey of Opinions of Students}

The statistical analysis began with the calculation of basic descriptive characteristics for the three selected quantitative variables:

- $\quad$ experience-gained in work related to project management (in years);

- foreign languages-the number of acquired foreign language skills;

- recommendations-the number of references held by previous employers.

The results figures for selected variables are presented in Table 2 .

\subsubsection{Interpretations of the Experience Variable}

When defining the minimum experience of a candidate for the position of a project manager, the respondents indicated the shortest period to be 1 year and as the longest one as 5 years. The average period of experience as a project manager or a similar opinion of students was around 2.108 years. The difference between the longest and shortest period of required experience indicated by the respondents was 4 years. The periods of experience indicated by the surveyed students differed by an average of 1.048 years from the average length of experience required in the recruitment process, which was $49.7 \%$ of the average length. That value means there was a significant variation in observations.

\subsubsection{Interpretations of the Foreign language Variable}

Respondents indicated at least one language and up to three languages as the minimum number of foreign languages that a participant in the recruitment process should have a command of to be eligible for the position of a project manager. According to students, a candidate for that position should know two foreign languages on average. At the same time, it is the variable value most frequently indicated by respondents. The difference between the largest and minimum number of foreign languages indicated by the respondents was two. The minimum number of foreign languages suggested by students differed by 0.704 from the average number of languages implied in the study, which was $37.8 \%$ of the arithmetic average. That diversity is significant.

\subsubsection{Interpretations of the Recommendation Variable}

In student opinion, at least one recommendation and a maximum of five recommendations should be required during the recruitment process. In addition, the average candidate for the position of a project manager should have at least two recommendations. The number of recommendations indicated by the surveyed students differed on average by about one recommendation from the average number of recommendations required in the recruitment process, which was almost $42 \%$ of the arithmetic average. That value means there was a significant variation in observations.

\subsection{Expert Research}

The next stage of the study was to verify the consistency of student opinions on the importance of individual competences in three areas-people, practice, and perspective-with expert assessments. Interviews were conducted with nine experts whose task was to give weight to and assess the significance of individual competences in the recruitment process. For this purpose, an expert evaluation questionnaire was created in which experts gave the importance of a competence in the set and assessed the significance of individual competences in the recruitment process for the project manager position.

Experts gave importance to individual competences in the right set of competences: people, competences, and practice. The total score of the competency weights in each set should equal 10 . In addition, the experts ranked each competence by assigning significance on a five-item scale (from 
one $=$ definitely insignificant, to five $=$ definitely important) in the recruitment process for the position of a project manager.

Experts participating in the study were people specializing in project management at diversified advancement levels. Two experts represented the area of human resources management (recruitment area), three of the experts were higher education employees in the field of management sciences (project management), two experts represented project manager certification institutions in accordance with the standards of individual competence guidelines (assessors), and two were industry project managers in the field of computing. All the experts, despite various specializations, were assessors and trainers of IPMA certification, and therefore their intentional selection is justified in the study.

\section{Results}

On the basis of the weights and assessments given by the survey experts, the relevance of the competences in the recruitment process for the position of a project manager allowed us to calculate the standardized weight of the individual competences $\left(Z_{e_{n}}\right)$ using the formula:

$$
Z_{e_{n}}=\frac{\sum_{i=1}^{n} w_{k_{n}} o_{k_{n}}}{10}
$$

where:

$n$-the number of competences included;

$w_{k_{n}}$-significance of the nth competence in the set;

$o_{k_{n}}$-assessment of the relevance of the nth competence in the set.

Similar to the expert assessment, student opinions were normalized, and standardized student assessment weights were obtained $-Z_{s_{n}}$. Since the students' responses were zero-one, it was necessary to determine $s, l_{u_{n}}, s_{u_{n}}$ factors to calculate the weight function of competence. These were used in the formula:

$$
Z_{s_{n}}=\frac{\frac{s_{u_{n}}}{s \cdot l_{u_{n}}}}{\sum_{i=1}^{n} \frac{s_{u_{n}}}{s \cdot l_{u_{n}}}},
$$

where:

$l_{u_{n}}$-the number of skills under the nth competence in the set;

$\mathrm{s}$ - the number of students surveyed;

$s_{u_{n}}$-the sum of the skills selected by students under the nth competence in the set.

In order to compare and correlate the weights of the experts and students, average weights were calculated for each competence within four groups of experts: representatives of higher education, assessors of project management certification, recruitment specialists, and IT project managers. The average weights represent the position of an average expert in a given field of project management on the importance of individual competence in the recruitment process for the position of project manager.

The weights of the significance of individual competences in the examined sets: the people, practice, and perspective calculated on the basis of student opinions and average expert assessments were put together and presented in Table 2.

The analysis shows that in the area of human competence, according to students, the most important is internal consistency and reliability. According to representatives of higher education, interpersonal communication is the most important competence. According to assessors of leadership and recruitment experts, leadership and teamwork are equally important and most important. According to experienced IT project managers in the recruitment process, leadership and interpersonal communication play the most important role. It can also be concluded from the above table that leadership is considered to be significant competence of a project manager according to experts in various areas of project management. 
Table 2. Comparison of students' and experts' assessment of people-related competence.

\begin{tabular}{cccccc}
\hline Competence & Students & $\begin{array}{c}\text { Higher Education } \\
\text { Experts }\end{array}$ & $\begin{array}{c}\text { Certification } \\
\text { Experts }\end{array}$ & $\begin{array}{c}\text { Recruitment } \\
\text { Experts }\end{array}$ & $\begin{array}{c}\text { IT Project } \\
\text { Managers }\end{array}$ \\
\hline $\begin{array}{c}\text { Self-reflection and } \\
\text { self-management }\end{array}$ & 0.11 & 0.07 & 0.08 & 0.11 & 0.04 \\
\hline Personal integrity and reliability & 0.12 & 0.06 & 0.06 & 0.06 & 0.06 \\
\hline Personal communication & 0.11 & 0.22 & 0.11 & 0.12 & 0.22 \\
\hline Relationships and engagement & 0.11 & 0.10 & 0.08 & 0.10 & 0.08 \\
\hline Leadership & 0.10 & 0.08 & 0.17 & 0.17 & 0.21 \\
\hline Teamwork & 0.10 & 0.16 & 0.12 & 0.17 & 0.05 \\
\hline Conflict and crisis & 0.10 & 0.07 & 0.10 & 0.05 & 0.08 \\
\hline Resourcefulness & 0.10 & 0.08 & 0.07 & 0.10 & 0.06 \\
\hline Negotiation & 0.07 & 0.08 & 0.07 & 0.02 & 0.15 \\
\hline Results orientation & 0.09 & 0.08 & 0.13 & 0.09 & 0.06 \\
\hline
\end{tabular}

In the area of individual technical competences (practice), students regarded change and transformation as the key technical competence during the recruitment process for the position of project manager (Table 3). Higher education experts in project management have indicated the definition of the project as well as the requirements, objectives, and benefits to be the most important technical competence. According to certification experts, they also include requirements, goals, and benefits, as well as planning and control. Recruitment experts indicated finance as the most desirable competence, while representatives of the IT industry regarded the scope and definition of the project as the significant competence. Discrepancies in the assessments of experts on competence in the field of practice resulted from the fact that in each of these four areas, the projects implemented with the specific objectives and experience of project managers are different from one another.

Table 3. Comparison of students' and experts' assessment of practice-related competence.

\begin{tabular}{cccccc}
\hline Competence & Students & $\begin{array}{c}\text { Higher Education } \\
\text { Experts }\end{array}$ & $\begin{array}{c}\text { Certification } \\
\text { Experts }\end{array}$ & $\begin{array}{c}\text { Recruitment } \\
\text { Experts }\end{array}$ & $\begin{array}{c}\text { IT Project } \\
\text { Managers }\end{array}$ \\
\hline Design & 0.07 & 0.11 & 0.09 & 0.08 & 0.11 \\
\hline $\begin{array}{c}\text { Requirements, objectives, and } \\
\text { benefits }\end{array}$ & 0.08 & 0.11 & 0.13 & 0.05 & 0.04 \\
\hline Scope & 0.06 & 0.07 & 0.09 & 0.03 & 0.13 \\
\hline Time & 0.09 & 0.06 & 0.08 & 0.12 & 0.04 \\
\hline Organization and information & 0.08 & 0.08 & 0.10 & 0.08 & 0.33 \\
\hline Quality & 0.07 & 0.07 & 0.02 & 0.06 & 0.04 \\
\hline Finance & 0.06 & 0.03 & 0.06 & 0.17 & 0.00 \\
\hline Resources & 0.08 & 0.04 & 0.02 & 0.06 & 0.04 \\
\hline Procurement and partnership & 0.09 & 0.03 & 0.09 & 0.03 & 0.00 \\
\hline Plan and control & 0.07 & 0.07 & 0.12 & 0.08 & 0.09 \\
\hline Risk and opportunity & 0.08 & 0.13 & 0.08 & 0.14 & 0.05 \\
\hline Stakeholders & 0.07 & 0.10 & 0.06 & 0.03 & 0.08 \\
\hline Change and transformation & 0.10 & 0.10 & 0.06 & 0.08 & 0.04 \\
\hline
\end{tabular}

In the case of contextual competence (Table 4), discrepancies in the assessments of experts and students are not as visible in the case of human and practical competences, which result from the fact that the perspective area is the least numerous in terms of the number of competences. Expert assessment has shown that two sets of competences are most important for students: management oversight, structure, and process; as well as the balance of power and interests. Higher education 
experts ranked the importance of strategy competence top, while certification experts recognized culture and values as the most important competences. A similar position was taken by specialists in recruitment and IT project managers who ranked strategy, culture, and values top. Using the calculated competence weights, one can analyze the correlation of Spearman's rank order with the average assessments of the expert and the project management students. To validate the rank correlation, the authors used the $p$-value statistical significance test. Statistical significance was assumed at the level of $p=0.1$. The null hypothesis assumes a strong correlation between the fields of project management, represented by the groups of experts, and the competences necessary for proper project management. In the tables, the correlations that are significant at the level of $p=0.1$ are marked in red.

Table 4. Comparison of students' and experts' assessment of perspective-related competence.

\begin{tabular}{cccccc}
\hline Competences & Students & $\begin{array}{c}\text { Higher Education } \\
\text { Experts }\end{array}$ & $\begin{array}{c}\text { Certification } \\
\text { Experts }\end{array}$ & $\begin{array}{c}\text { Recruitment } \\
\text { Experts }\end{array}$ & $\begin{array}{c}\text { IT Project } \\
\text { Managers }\end{array}$ \\
\hline Strategy & 0.17 & 0.23 & 0.22 & 0.33 & 0.33 \\
\hline $\begin{array}{c}\text { Governance, structures and } \\
\text { processes }\end{array}$ & 0.23 & 0.11 & 0.22 & 0.18 & 0.06 \\
\hline $\begin{array}{c}\text { Compliance, standards and } \\
\text { regulation }\end{array}$ & 0.18 & 0.19 & 0.19 & 0.12 & 0.04 \\
\hline Power and interest & 0.23 & 0.15 & 0.12 & 0.09 & 0.21 \\
\hline Culture and values & 0.20 & 0.33 & 0.25 & 0.29 & 0.35 \\
\hline
\end{tabular}

Spearman's correlation coefficients for the experts' and students' assessment weights were calculated by means of the formula:

$$
r_{s}=1-\frac{6 \sum_{i=1}^{n} d_{i}^{2}}{n\left(n^{2}-1\right)}
$$

where:

$d_{i}$-score difference $Z_{s_{n}}-Z_{e_{n}}$,

$n$-the number of competences in the set.

For the purpose of the study, Spearman's rank correlation coefficients were determined by using the Statistica program and tools for calculating nonparametric statistics. The results of the Spearman rank correlation analysis for the experts' and students' assessments are presented in Table 5 for each set of competences: human, technical, and contextual.

Table 5. Rank correlation coefficients for experts' and students' assessments of people-related competence.

\begin{tabular}{cccccc}
\hline \multicolumn{5}{c}{ Spearman's Rank Correlation Coefficients for Human Competence } \\
\hline Rank & Students & Higher Education & Certification & Recruitment & IT Projects \\
\hline Students & 1.0 & & & & \\
\hline Higher Education & -0.1 & 1.0 & & & \\
\hline Certification & -0.2 & 0.3 & 1.0 & & \\
\hline Recruitment & 0.2 & 0.6 & 0.6 & 1.0 & 1.0 \\
\hline IT Projects & 0.1 & 0.4 & 0.2 & -0.1 & \\
\hline
\end{tabular}

The Spearman's rank correlation coefficient analysis for a set of human competences shows a weak correlation for assessing the validity of competences assigned by students and experts. The correlation is negative for students and experts in higher education and certification assessors. while it is positive for students and experts for recruitment and IT project managers. There is a $10 \%$ probability of obtaining the results we can see in Table 5 or even results indicating a strong relationship between the meaning of human competence and the opinions of experts. The above analysis shows that there 
is a significant correlation in two cases: between recruitment experts and representatives of higher education and between recruitment experts and certification assessors.

For the set of technical competence, the Spearman's rank order correlation analysis indicates a weak negative correlation between student grades and the assessment of certification experts, recruitment, and IT projects. A weak but positive rank correlation exists between student opinion and the assessment of higher education representatives. A weak but visible correlation is evidenced for the assessment of certification assessors and the representatives of higher education. The analysis showed that, for technical competences, there is a $10 \%$ probability that a significant strong correlation exists between the representatives of higher education and IT project management practitioners and between certification assessors and IT project management practitioners (Table 6.).

Table 6. Rank correlation coefficients for experts' and students' assessments of practice-related competence.

\begin{tabular}{cccccc}
\hline \multicolumn{6}{c}{ Spearman's Rank Correlation Coefficients for Human Competence } \\
\hline Rank & Students & Higher Education & Certification & Recruitment & IT Projects \\
\hline Students & 1 & & & & \\
\hline Higher education & 0.1 & 1 & & & \\
\hline Certification & 0.0 & 0.4 & -0.1 & 1 & \\
\hline Recruitment & -0.1 & 0.1 & 0.5 & 0.0 & 1 \\
\hline IT Projects & -0.3 & 0.6 & &
\end{tabular}

The results of the Spearman's rank correlation analysis for a set of contextual competences have shown the strongest alignments between the experts' and students' assessments. A very strong negative correlation occurred between the assessment of students and project management experts in higher education. A slightly lower but also negative correlation occurred in the case of recruitment specialists. A weak negative correlation of students' and experts' assessments occurred for representatives of project certification bodies and IT project managers. In addition, the analysis has shown that the rating given by higher education experts proves a strong positive correlation with other groups of experts: certification assessors, recruitment specialists, and IT project managers. The strongest alignment of rating has been noted for the weights assigned to competence by recruitment specialists and certification assessors (Table 7). The above correlation shows that there is a $10 \%$ probability that there is a very strong relationship in the assessment of contextual competence between recruitment experts and certification assessors, assuming that the null hypothesis is true.

Table 7. Rank correlation coefficients for experts' and students' assessments of perspective-related competence.

\begin{tabular}{cccccc}
\hline \multicolumn{7}{c}{ Spearman's Rank Correlation Coefficients for Human Competence } \\
\hline Rank & Students & Higher Education & Certification & Recruitment & IT Projects \\
\hline Students & 1 & & & & \\
\hline Higher Education & -0.7 & 1 & & & \\
\hline Certification & -0.3 & 0.7 & 0.9 & 1 & 1 \\
\hline Recruitment & -0.5 & 0.6 & 0.7 & 0.6 & 1 \\
\hline IT Projects & -0.2 & 0.7 & & & \\
\hline
\end{tabular}

\section{Discussion}

In Poland, the field of project management has been popular recently and many universities have just taken their first steps in implementing project management into their learning plan. The study was attended by students of three universities that belong to the group of the most advanced universities in terms of educating in the project management area. Additionally, it was assumed that 
the implementation of the $35 \%$ sample was sufficient for students. The purpose of this study was to check student reviews to outline the right direction for future research, which is also currently being performed. In addition, it is recommended to include all universities accredited by IPMA Poland in the further stages of the study. Our research indicates discrepancies in the approach to the key competences that a project manager should have. This is understandable, given the specifics of the comparison. However, the conducted analysis will allow the curricula to be revised and contribute to the evaluation of education programs, taking into account changes in the labor market and the key role of universities in the development of countries [43]. Furthermore, it is advisable to update the education program, as after graduation students should be equipped with a full spectrum of competences and approaches. They also should understand the increasing importance of project managers and the future development of the role of project managers from deputy managers to responsible entrepreneurs. It requires all-round development from graduates if they would like to live up to employers' expectations. It should also be kept in mind that competence is, by definition, variable and dynamic, just as economic conditions are changing, volatile, and dynamic today. Competence carries the need for alignment with the specificity of the organization and its environment [44], as well as the need for continuous development in the field of curriculum adaptation [45]. It should be emphasized that the study has the features of creativity and innovation. Our study is the first study in Poland conducted among students accredited by IPMA Poland. In addition, student research based on several universities is very demanding and time-consuming for logistical and administrative reasons. We believe that in the initial phase of the research project, research in the form of an interview questionnaire was a sufficient way to obtain data. Of course, we assume that the future development of research will enable us to measure the level of students' competences no longer by means of questionnaire questions, but by practical tasks that will allow us to assess the level of advancement of individual competences.

\section{Conclusions}

Professional experience is a very important factor in professional development and competence development [46]. However, education should guarantee the acquisition of key competences. Besides experience, project management is the most frequently pursued competence that is required in terms of staff recruitment criteria [12,37]. Education should be adapted to the new challenges posed by globalization $[38,39]$.

The research results indicate differences in the identification of competence needed to be pursued by a project manager, both between students and experts as well as the experts themselves. In the area of human competence, according to students, internal coherence and reliability are the most important; according to representatives of higher education, interpersonal communication is the most important; and according to assessors of certification, leadership. According to recruitment experts, leadership and teamwork are equally important; according to experienced managers of IT projects, they are the most important. In the recruitment process, the most important role is played by leadership and interpersonal communication. In the area of technical competence (practice), students regard change and transformation as the key technical competence during the recruitment process for the position of project manager. Higher education experts in project management have indicated the definition of the project as well as requirements, objectives, and benefits to be the most important technical competence. According to certification experts, apart from requirements, goals, and benefits, planning and control matter, too. Recruitment experts have indicated finance to be the most desirable competence, while representatives of the IT industry value the scope and definition of the project.

In the case of contextual competences, discrepancies in the assessment of experts and students are not as visible as in the case of human and practical competence, which results from the fact that the perspective area is the least numerous in terms of the number of competences. Experts' assessment has shown that two competences are most important for students: management oversight, structure, and process; as well as balance of power and interests. Higher education experts indicate strategy 
competence to be the most important, while certification experts recognize culture and values as the most important competence. A similar position is shared by specialists in recruitment and IT project managers, who rank strategy, culture, and values top.

Therefore, the conclusion suggests the need to conduct a systematic study of project manager competences, bearing in mind the expectations of students, the stakeholders themselves-i.e., project managers-as well as experts. The cooperation of all stakeholders is crucial in order to develop the best education program. A program that develops the competence necessary for project managers may bring about the achievement of measurable benefits in the future, for example, by preventing the failure of projects [47].

The authors are also aware that practice is one of the competence providers for project managers. Therefore, it was assumed that the purpose of the article would be to check to what extent studies preparing for the profession of project manager are in line with practice, at least in terms of expectations.

The presented research results may be useful for recruiters by indicating the key competence necessary to work as project managers; certification institutions, by indicating the differences between expectations and the actual assessment of competences; and universities that may use it for the purpose of the modification of teaching programs.

The results will also improve the quality of education in the field of project management by adapting students' competences to the competences required by the labor market.

Author Contributions: Data curation, M.Z.; funding acquisition, M.S.; methodology, A.S.; writing-original draft, M.S.; writing-review and editing, S.J. All authors have read and agreed to the published version of the manuscript.

Funding: This research was funded by the Ministry of Science and Higher Education within the "Regional Initiative of Excellence" Program for 2019-2022. Grant number 021/RID/2018/19. Total financing: 11897 131,40 PLN.

Conflicts of Interest: The authors declare no conflict of interest.

\section{References}

1. International Project Management Association. Individual Competence Baselie Vol.4.0; International Project Management Association: Zurich, Switzerland, 2015.

2. Louart, P. Kierowanie Personelem w Przedsiębiorstwie; Poltext: Warszawa, Poland, 1995.

3. Project Management Institute. Project Manager Competency Development (PMCD) Framework, 2nd ed.; Project Management Institute: Newton Square, PA, USA, 2007.

4. Gick, A.; Tarczyńska, M. Motywowanie Pracowników: Systemy, Techniki, Praktyka; Polskie Wydawnictwo Ekonomiczne: Warszawa, Poland, 1999.

5. Boyatzis, R.E. The Competent Manager: A Model for Effective Performance; Wiley: New York, NY, USA, 1982.

6. Bredin, K.; Söderlund, J. Project managers and career models: An exploratory comparative study. Int. J. Proj. Manag. 2013, 31, 889-902. [CrossRef]

7. Alvarenga, J.C.; Branco, R.R.; Guedes, A.L.A.; Soares, C.A.P.; E Silva, W.D.S. The project manager core competencies to project success. Int. J. Manag. Proj. Bus. 2019, 13, 277-292. [CrossRef]

8. Aubry, M.; Lièvre, P. Ambidexterity as a competence of project leaders: A case study from two polar expeditions. Proj. Manag. J. 2010, 41, 32-44. [CrossRef]

9. Nicholas, J.M.; Steyn, H. Project Management for Engineering, Business and Technology, 4th ed.; Routledge: London, UK, 2012.

10. Savelsbergh, C.M.J.H.; Havermans, L.A.; Storm, P. Development paths of project managers: What and how do project managers learn from their experiences? Int. J. Proj. Manag. 2016, 34, 559-569. [CrossRef]

11. Clarke, N. Emotional intelligence and its relationship to transformational leadership and key project manager competencies. Proj. Manag. J. 2010, 41, 5-20. [CrossRef]

12. Pant, I.; Baroudi, B. Project management education: The human skills imperative. Int. J. Proj. Manag. 2008, 26, 124-128. [CrossRef]

13. White, D.; Fortune, J. Current Practice in Project Management-An Empirical Study. Int. J. Proj. Manag. 2002, 20, 1-11. [CrossRef] 
14. Bredillet, C.; Tywoniak, S.; Dwivedula, R. What is a good project manager? An Aristotelian perspective. Int. J. Proj. manag. 2014, 33. [CrossRef]

15. Ling, F.Y.Y.; Ning, Y.; Chang, Y.H.; Zhang, Z. Human resource management practices to improve project managers' job satisfaction. Eng. Constr. Archit. Manag. 2018, 25, 654-669. [CrossRef]

16. Tittel, A.; Terzidis, O. Entrepreneurial competences revised: Developing a consolidated and categorized list of entrepreneurial competences. Entrep. Educ. 2020, 3, 1-35. [CrossRef]

17. Behling, G.; Lenzi, F.C. Entrepreneurial competencies and strategic behavior: A study of micro entrepreneurs in an emerging country. Braz. Bus. Rev. 2019, 16, 255-272. [CrossRef]

18. Karpacz, J. Entrepreneurial Orientation and the Development of the Dynamic Capabilities-The Scientific Literature Context. t. 19, z. 3, cz. 1 Uwarunkowania rozwoju regionalnego i lokalnego. Przedsiębiorczość $i$ Zarzadzanie 2018, 109-126.

19. Stevenson, D.H.; Starkweather, J.A. PM critical competency index: IT execs prefer soft skills. Int. J. Proj. Manag. 2010, 28, 663-671. [CrossRef]

20. Teubner, R.A. IT program management challenges: Insights from programs that ran into difficulties. Int. J. Inf. Syst. Proj. Manag. 2018, 6, 71-92. [CrossRef]

21. Obradovic, V.; Jovanovic, P.; Petrovic, D.; Mihic, M.; Bjelica, D. Web-based Project Management Influence on Project Portfolio Managers' Technical Competencies. Procedia - Soc. Behav. Sci. 2014, 119, 387-396. [CrossRef]

22. An, N.; Qiang, M.; Wen, Q.; Jiang, H.; Xia, B. Contribution of project managers' capability to project ending performance under stressful conditions. Eur. Manag. J. 2019, 37, 198-209. [CrossRef]

23. Wu, G.; Liu, C.; Zhao, X.; Zuo, J. Investigating the relationship between communication-conflict interaction and project success among construction project teams. Int. J. Proj. Manag. 2017, 35, 1466-1482. [CrossRef]

24. Clarke, $\mathrm{N}$. The impact of a training programme designed to target the emotional intelligence abilities of project managers. Int. J. Proj. Manag. 2010, 28, 461-468. [CrossRef]

25. Kasvi, J.J.J.; Vartiainen, M.; Hailikari, M. Managing knowledge and knowledge competences in projects and project organisations. Int. J. Proj. Manag. 2003, 21, 571-582. [CrossRef]

26. Crawford, L.; Nahmias, A.H. Competencies for managing change. Int. J. Proj. Manag. 2010, $28,405-412$. [CrossRef]

27. Havila, V.; Medlin, C.J.; Salmi, A. Project-ending competence in premature project closures. Int. J. Proj. Manag. 2013, 31, 90-99. [CrossRef]

28. Müller, R.; Turner, R. Leadership competency profiles of successful project managers. Int. J. Proj. Manag. 2010, 28, 437-448. [CrossRef]

29. Derakhshan, R.; Turner, R.; Mancini, M. Project governance and stakeholders: A literature review. Int. J. Proj. Manag. 2019, 37, 98-116. [CrossRef]

30. Binder, J. Global Project Management: Communication, Collaboration and Management across Borders. Strategic Direction 2009, 25. [CrossRef]

31. Martens, C.D.P.; Machado, F.J.; Martens, M.L.; Silva, F.Q.P.; De Freitas, H.M.R. Linking entrepreneurial orientation to project success. Int. J. Proj. Manag. 2018, 36, 255-266. [CrossRef]

32. Do Vale, J.W.S.P.; Nunes, B.; De Carvalho, M.M. Project Managers' Competences: What Do Job Advertisements and the Academic Literature Say? Proj. Manag. J. 2018, 49, 82-97. [CrossRef]

33. Martinsuo, M.; Hoverfält, P. Change program management: Toward a capability for managing value-oriented, integrated multi-project change in its context. Int. J. Proj. Manag. 2018, 36, 134-146. [CrossRef]

34. Ahmad, S.; Schroeder, R.G. The importance of recruitment and selection process for sustainability of total quality management. Int. J. Qual. Reliab. Manag. 2002, 19, 540-550. [CrossRef]

35. Chen, Y.G.; Cheng, J.N. The relationships among recruitment channels, understanding of perspective job, job performance and turnover intention among Taiwanese kindergarten teachers. Soc. Behav. Personal. 2012, 40, 93-103. [CrossRef]

36. Otoo, F.N.K. Human resource management (HRM) practices and organizational performance: The mediating role of employee competencies. Empl. Relat. 2019, 41, 949-970. [CrossRef]

37. Anantatmula, V.S.; Shrivastav, B. Evolution of project teams for Generation Y workforce. Int. J. Manag. Proj. Bus. 2012, 5, 9-26. [CrossRef]

38. Mateo, J.R.S.C.; De Navamuel, E.D.R.; Villa, M.A.G. Are project managers ready for the 21th challenges? A review of problem structuring methods for decision support. Int. J. Inf. Syst. Proj. Manag. 2017, 5, 43-56. [CrossRef] 
39. Zhiwen, G.; Van der Heijden, B.I.J.M. Employability enhancement of business graduates in China: Reacting upon challenges of globalization and labour market demands. Educ. Train. 2008, 50, 289-304. [CrossRef]

40. PMI. The Project Manager of the Future: Developing Digital-Age Project Management Skills to Thrive in Disruptive Times; Project Management Institute: Newtown Square, PA, USA, 2018.

41. Gemuenden, H.G.; Schoper, Y. Future Trends in Project Management Editor-in-Chief of Project Management Journal View Project Relationship Marketing Teams View Project. 2015. Available online: https://www. researchgate.net/publication/303375998 (accessed on 11 March 2020).

42. Blomquist, T.; Farashah, A.D.; Thomas, J. Feeling good, being good and looking good: Motivations for, and benefits from, project management certification. Int. J. Proj. Manag. 2018, 36, 498-511. [CrossRef]

43. Cerezo-Narváez, A.; De los Rí os Carmenado, I.; Pastor-Fernández, A.; Yagüe Blanco, L.; Otero-Mateo, M. Project management competences and sustainable 2 development in higher education: Case studies from 3 two Spanish public universities. Preprints 2018, 4. [CrossRef]

44. Kor, Y.Y.; Mesko, A. Dynamic managerial capabilities: Configuration and orchestration of top executives' capabilities and the firm's dominant logic. Strateg. Manag. J. 2013, 34, 233-244. [CrossRef]

45. Nijhuis, S.; Vrijhoef, R.; Kessels, J. Tackling Project Management Competence Research. Proj. Manag. J. 2018, 49, 62-81. [CrossRef]

46. Paloniemi, S. Experience, competence and workplace learning. J. Workplace Learn. 2006, 18, 439-450. [CrossRef]

47. Ewin, N.; Luck, J.; Chugh, R.; Jarvis, J. Rethinking Project Management Education: A Humanistic Approach based on Design Thinking. Procedia Comput. Sci. 2017, 121, 503-510. [CrossRef]

(C) 2020 by the authors. Licensee MDPI, Basel, Switzerland. This article is an open access article distributed under the terms and conditions of the Creative Commons Attribution (CC BY) license (http://creativecommons.org/licenses/by/4.0/). 